\title{
Corrigendum
}

\section{On properly characterizing moral agency - CORRIGENDUM}

\section{Blaine J. Fowers, Austen R. Anderson, and Samantha F. Lang}

doi:10.1017/S0140525X1700067X. Published by Cambridge University Press, 27 March 2018

The middle initial of Samantha F. Lang was incorrect in the original online version of this commentary (Fowers et al. 2018) on the précis by Doris (2018). The initial has been corrected in the commentator heading above and in the original commentary as well.

\section{References}

Doris, J. M. (2018) Précis of Talking to Our Selves: Reflection, Ignorance, and Agency. Behavioral and Brain Science 41:e36.

Fowers, B. J., Anderson, A. R. \& Lang, S. F. (2018) On properly characterizing moral agency. Behavioral and Brain Science 41:e43. https://doi:10.1017/S0140525X1700067X. 